\title{
低炭素鋼板の大入熱溶接熱影響部の シャルピー衝撃破壊挙動とミクロ組織の関係
}

\author{
金築 裕* ・池田 英次 ${ }^{* 2}$ ・勝亦 正昭*3 \\ Relationship between Charpy Impact Toughness and \\ Microstructure in Heat Affected Zone of High Heat Input Low Carbon Steel Weldment \\ Yutaka Kanetsuki, Eiji Ikeda and Masaaki Katsumata
}

Synopsis : Although it has been known that toughness of heat affected zone (HAZ) in low carbon steels lowers with increasing heat input, high heat input welding has been demanded from economical reason. Toughness of HAZ has been often investigated using synthetic HAZ, but thermal cycle in high heat input welding has not been well known. The thermal cycle in tandem submerged arc butt welding in a low carbon steel was measured using thermocouples specially designed. Cooling rate of $\mathrm{HAZ}$ markedly changed in around $\mathrm{A}_{1}$ transformation temperature in high heat input welding, that is high cooling rate above the temperature and low cooling rate below the temperature. Toughness of synthetic $\mathrm{HAZ}$ of high heat input welding with high cooling rate above $700^{\circ} \mathrm{C}$ and low cooling rate below $700^{\circ} \mathrm{C}$ deteriorated compared with that of synthetic HAZ cooled at a constant low cooling rate. This result was related with degenerated pearlite precipitation in synthetic HAZ of high heat input welding.

Charpy impact absorbed energy of actual HAZ scatters in a wide temperature range of transition zone. This has disturbed to understand toughness of HAZ. The scattering of absorbed energy occurred in a narrow temperature range in synthetic HAZ and in a wider one by Izod impact test. It appears that the scattering of absorbed energy in actual HAZ is caused by strength heterogeneity of actual joints because of no strength heterogeneity in synthetic HAZ and larger strength heterogeneity by Izod impact test compared with Charpy impact test.

Key words : low carbon steel; high heat input welding; heat affected zone; Charpy impact test; Izod impact test ; strength heterogeneity; thermal cycle; degenerated pearlite.

\section{1. 緒言}

溶接構造物において, 溶接熱影響部(以下HAZと記す)の 勒性確保は非常に重要な問題であり，これまで材料および 施「法の両面から多くの検討がなされてきた。一般に大入 熱溶接として区別されている $50 \mathrm{~kJ} / \mathrm{cm}$ 以上の入熱量の場合, HAZの勒性が著しく劣化することが知られているが，施上 能率の改善や自動化の観点から大入熱溶接が指向されてい る ${ }^{1)}$ 。そのため，HAZ鞄性確保のための材料面での検討が改 めて望まれている。

HAZの勒性が劣化する原因は，結晶粒やミクロ組織の粗 大化にあることは良く知られている。勒性改善の手段とし て, 例えば, 微細炭窒化物による結晶粒の粗大化防止 ${ }^{2)}$ や酸 化物によるミクロ組織の微細化 ${ }^{3}$ 等の検討が試みられてきた が，入熱量が增大している現状ではまだ十分とは言えない。 また, 島状マルテンサイト等のHAZに特有の組織と勒性の
関係についても調查されている4)。しかし，HAZの組織は溶 融線からの距離とともに連続的に変化しているうえ，連続 冷却のため極めて不均質であり, 組織と勒性との関係が十 分把握されているとはいえない。さらに，実溶接継手HAZ においては衝撃遷移温度付近で吸収エネルギーがばらつく 温度範囲が広くなる傾向を有しており，このこともミクロ 組織と勒性の関係を明確にすることを困難にしている。一 方，HAZ勒性を評価するために，溶接熱サイクルをシミュ レートした再現HAZによる勒性評価が行われるが，大入熱 溶接時のHAZが受ける溶接熱サイクルを正確に測定した例 はみられない。

そこで，本報告では実際の大入熱溶接時の熱履歴を実測 し，その結果に基づいて大入熱熱サイクルの特徴を付与し たHAZ組織を再現し，その衝撃破壊挙動を実溶接継手 HAZの特性と併せて検討を行い, 大入熱溶接時の熱サイク ルと勒性の関係を調查するとともに溶接継手HAZの吸収工

壮成 9 年 7 月 8 月受付 半成 9 年10月1 月受理 (Received on July 8,1997 . Accepted on Oct 1, 1997)

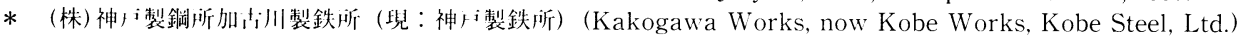

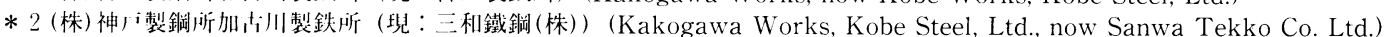

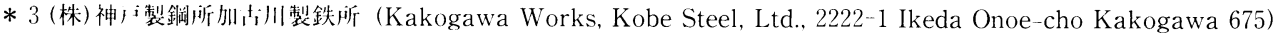


ネルギーのばらつきの原因を検討した。

\section{2. 実験方法}

\section{$2 \cdot 1$ 供試材および溶接条件}

Table 1 は供試材として用いた制御圧延・加速冷却（以下 TMCPと記す)によって製造した鋼板（板厚 $14 \mathrm{~mm}$ )の化学成 分を示寸。鋼板の組織は微細フェライト・パーライト組織 である。大入熱溶接方法には多電極サブマージアーク溶接, エレクトロスラグ溶接等があるが，本研究では 2 電極サブ マージアーク溶接を採用し，入熱量を $72 \mathrm{~kJ} / \mathrm{cm}$ と，幅 $200 \mathrm{~mm}$, 長さ $1,000 \mathrm{~mm}$ の鋼板に突き合わせ溶接を実施した。

Table 2 に溶接条件を示す。

\section{$2 \cdot 2$ HAZの再現熱サイクル条件}

HAZの熱サイクルについてはこれまでに稲坦ららにより測 走がなされ，それにもとづいて HAZ組織が模擬されること が多い。稲垣らの熱サイクルの測定は板面にビードを置き, その下部の温度を熱電対で測定している。しかしながら， 実際の溶接は板面にビードを置く場合に比べ複雑な熱履歴 をとり, 特に2 電極の場合は熱サイクルの状況が大きく異 なることが考えられる。したがって, 溶接継手の勒性と組 織の関係を評価するためには実際の熱サイクルの測定がぜ ひとも必要である。

本研究では, 確実にHAZの位置に熱電対を置き, かつ, 㤽確な熱サイクルを測定するために, Fig. 1 (A)に示す構成 の熱電対を製作した。この熱電対の特徵は， 3 本の応答性 の速い,十分に細い素線径 $0.2 \mathrm{~mm}$ の白金一白金ロジウム熱 電対を採用しこれらを軟鋼のシース $(\phi 3 \mathrm{~mm})$ に入れた点 にある。3本の熱電対はそれぞれステンレス鋼のシースに 入っているが，その先端(測定点)はシースから出ている。 熱電対の先端を軟鋼シースの内壁に $1 \mathrm{~mm}$ 間隔でスポット溶 接した。一本目の熱電対は軟鋼シースの先端から $1 \mathrm{~mm}$ の位 置に取りつけた。ここでの軟鋼シースの役割は熱電対の保 濩ではなく，素材(鋼板)の一部としての伝熱にある。この 軟鋼シースをFig. 1 (B)に示すように, 鋼板の板厚中心に, あらかじめ同一条件で溶接した鋼板より求めた溶融線の位 筒に軟鋼シースの先端がくるように, 介先最先端より $5 \mathrm{~mm}$

Table 1. Chemical compositions of steel used (mass\%).

\begin{tabular}{cccccccc}
\hline $\mathrm{C}$ & $\mathrm{Si}$ & $\mathrm{Mn}$ & $\mathrm{P}$ & $\mathrm{S}$ & $\mathrm{Al}$ & $\mathrm{Ti}$ & $\mathrm{N}$ \\
\hline 0.07 & 0.26 & 1.39 & 0.006 & 0.001 & 0.019 & 0.021 & 0.0040 \\
\hline
\end{tabular}

Table 2. Parameters of tandem submerge arc welding.

\begin{tabular}{|c|c|c|}
\hline Welding velocity & $: 60 \mathrm{~cm} / \mathrm{min}$ & Groove : Y \\
\hline Electrode distance & $35 \mathrm{~mm}$ & Wire : US-43 \\
\hline Heat input & $72 \mathrm{~kJ} / \mathrm{cm}$ & \\
\hline
\end{tabular}

の位置に挿入，固定した。軟鎙シースは鎙板との䦌隙がで きるだけ小さくなるように装着した。軟釗シースの最先端 付近は溶接により溶融一凝固し, 溶接全属々密洋し, 熱の 主な流れ方向である軟鋼シースの表手う们の䦌隙は全くな い。

再現熱サイクル武騃は50kWの菖成波加熱熱サイクル将現 装置を用い，厚さ $12.5 \mathrm{~mm}$, 幅 $31 \mathrm{~mm}$, 店さ $55 \mathrm{~mm}$ の武騒 を用いた。熱電対は $\phi 0.3 \mathrm{~mm}$ の门金一门金口ジウム線を朋 い, 試験片の幅と長さで用まれる自の幅端から $2.5 \mathrm{~mm}$, 长 さ端から27.5mmの位置に 熱電対を取りつけた。試騃条作は答测にもとづいて設走し たが，詳細は結果とともに後述する。紬織観祭はフォーマ スター試験機により熱サイクルを付り $j$ した战験けについて 透過電子顕微鏡 (以下TEMと䛉す) を打いて行った。

\section{$2 \cdot 3$ 衝撃試験方法}

溶接継手HAZと再現HAZの勒性をシャルピー武験により 評価した。Fig. 2 (A)は浴接継手からの試験けの採取估置を 示すもので，ノッチの位置は浴融線から快材側に $1 \mathrm{~mm}$ の HAZ（熱サイクルを実測した住置に刘応）とした。また，溶 接金属の中央にノッチをつけたシャルピー條験も先施した。 Fig. 2 (B), (C)は衝撃值のばらつきの原因を検咕寸るために 用いたアイゾット試験师の採取位置をホしており，ノッチ と溶接線の位置関係はFig. 2 (A) と间様である。Fig. 2 (B),

(A)

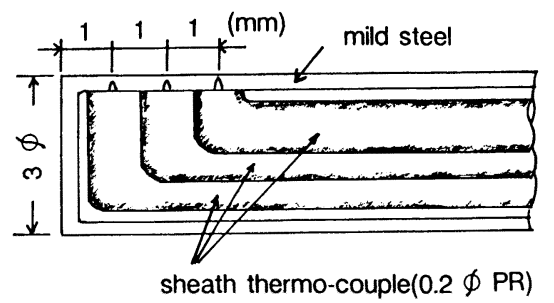

(B)

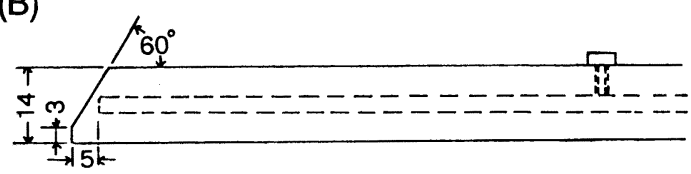

Fig. 1. Schematic illustrations of the specially designed thermocouple (A), shape of groove and location of thermocouple (B).

(A)
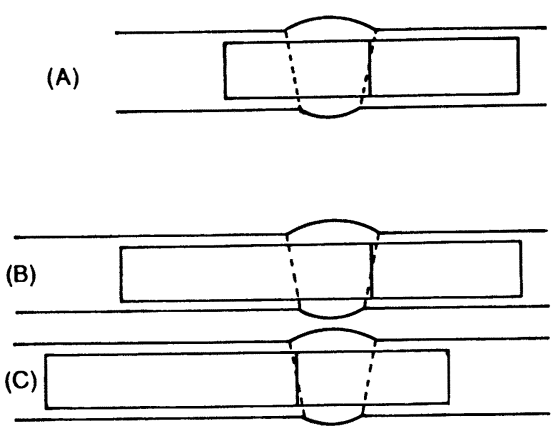

Fig. 2. Extraction of Charpy (A) and $\operatorname{Izod}(\mathrm{B}, \mathrm{C})$ specimens. 
(C)の違いは打撃側の組織が異なるようにノッチをつけたも ので，それぞれ打撃側組織が村材，溶接金属の場合に対応 する。

再現HAZの衝撃試験は再現熱サイクル材から切り出した シャルピー試験片により行った。

\section{3. 実験結果}

\section{$3 \cdot 1 \quad$ 溶接継手のマクロ組織と硬さ分布}

溶接継手の横断面マクロ組織をFig. 3 に示寸。溶け迄み形 状は片側では溶融線が板面に対してほぼ垂直で，他方では 傾斜している。溶け込み形状は衝撃試験片の)ッチと溶融 線の位置関係に影響する。その結果, ノッチ下部の場所に よる組織に影響を及ばし, 吸収エネルギーのばらつきや遷

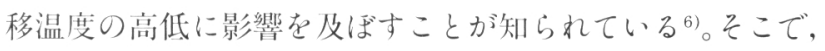
試験片製作に伴う組織的不均質をできるだけ少なくし，こ れに伴う吸収エネルギーのばらつきへの影響去少なくする ため, 垂直側にノッチを付け, HAZ組織の勒性を評価した。

Fig. 4 に溶接継手の板厚中央でのビッカース硬さ分布を示 す。本実験材では，溶接金属の硬さが母材より高く，母材 との硬さ比で1.4のオーバーマッチング7である。

\section{$3 \cdot 2$ 大入熱溶接時のHAZの熱サイクル}

2 電極サブマージアーク溶接支T Table 2 に示す条件で行っ

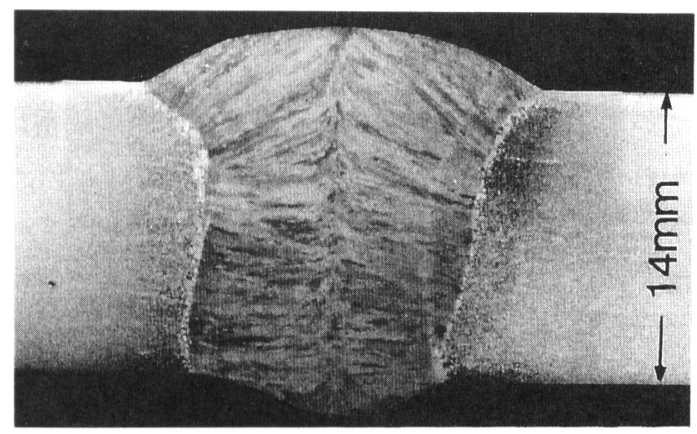

Fig. 3. Optical micrograph of weld zone.

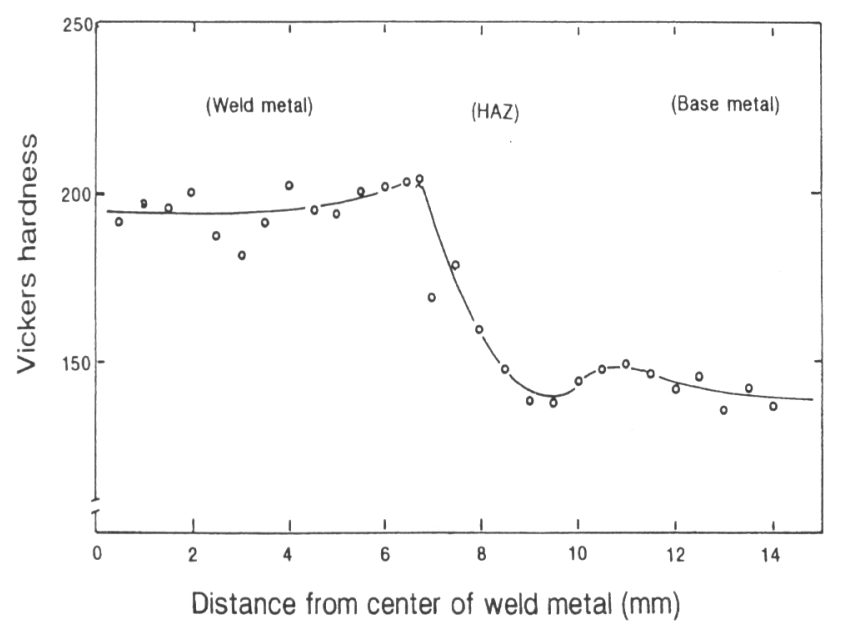

Fig. 4. Vickers hardness distribution of weld zone.
た時のHAZでの温度測定結果をFig. 5 に示す。Fig. 6 は溶接 継手のX線透過写真で, 溶接後の測定点の位置走している。 X線は鋼板上面から板厚方向に照射され, 鋼板下面に置いた フィルムを感光させた。黒い部分が溶接金属に対応してお り, 溶接金属に直角の線は 2 組の熱電対(ただし，1組は溶 融線の位置のブレを想定して子備的な目的で入れたもの)に 対応している。熱電対に沿った切断面の観察から, Fig. 5 の 测定結果は左側の熱電対で測定した 3 点のうちの 2 点であ ることが確認された。先端の熱電対は溶融のために断線し たが, 続く熱電対は溶融線(ボンド部)にほぼ対応した位置 にあり，Fig. 5 のボンド (bond)で表示した測定結果が得ら れた。3 番目の熱電対は溶融線から 1 〜 $\mathrm{mm}$ の位置に対応 しており，その測定結果法Fig. 5 中HAZで表示している。 bondおよびHAZでの測定結果のいずれも加熱速度は約 500 ${ }^{\circ} \mathrm{C} / \mathrm{s}$ で, それぞれの最高加熱温度で約 5 s保持されることが わかった。また, 冷却時は最高加熱温度から $900^{\circ} \mathrm{C}$ までは約 80 ${ }^{\circ} \mathrm{C} / \mathrm{s}, 700^{\circ} \mathrm{C}$ か は約 $6^{\circ} \mathrm{C} / \mathrm{s}$ の徐冷と, $\mathrm{A}_{1}$ 変態温度近傍で冷 却速度が大きく変化することがわかった。

大入熱溶接の場合, 溶接部近傍の鋼板が比較的広範囲に わたり, 溶接熱により加熱され $500^{\circ} \mathrm{C}$ 程度となる(小入熱溶接 では $200^{\circ} \mathrm{C}$ 程度 $\left.{ }^{5}\right)$ ため, $700^{\circ} \mathrm{C}$ 以下の泠却速度が遅くなると 考えられる。従来, 小入熱溶接の再現HAZの冷却は, 变態

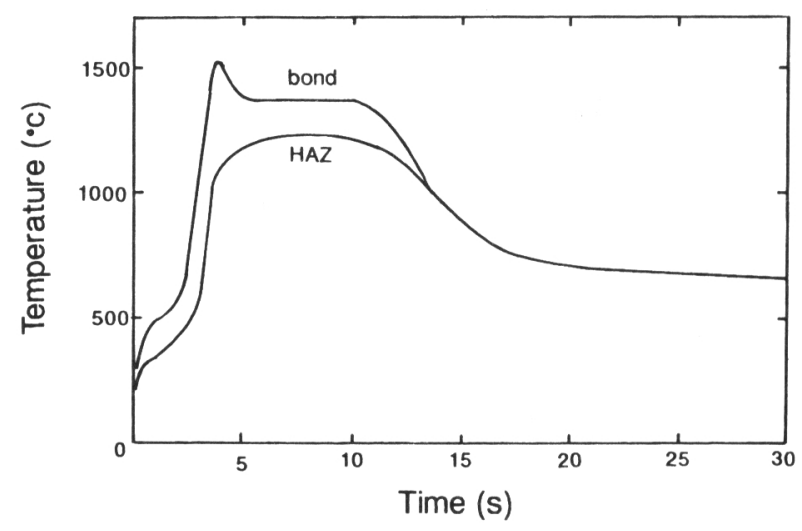

Fig. 5. Measured welding thermal cycle.

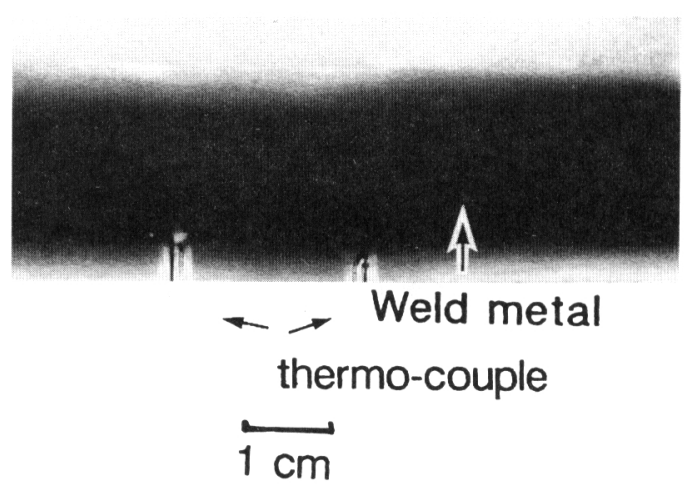

Fig. 6. X-ray photograph of welded steel plate with thermocouples. 
が関与する $800^{\circ} \mathrm{C}$ か $5300^{\circ} \mathrm{C}$ 平均冷却速度で代表させた冷却 のみに注目され，行われるのが一般的である5)。しかしなが 5 , 本結果は大入熱溶接の場合にはこの温度域を等速冷却 として扱うことに問題があることを示唆している。そこで, 本研究での熱サイクルは単純化したFig. 7 に示す 2 段階の泠 却パターンA (以下実測パターンと記す)とした。また, 比較 のため， 1 段の等速 $\left(6^{\circ} \mathrm{C} / \mathrm{s}\right)$ 冷却パターン $\mathrm{B}$ 試験した。

\section{$3 \cdot 3$ 溶接継手および再現熱サイクル材のシャルピー衝撃 試験結果}

Fig. 8 に溶接継手のシャルピー試験結果を吸収エネルギー と試験温度の関係で示している。溶融線から母材側に $1 \mathrm{~mm}$ の)ッチ位置の場合, $-40^{\circ} \mathrm{C}$ 以下の温度で吸収エネルギー が低下し, 遷移温度域でのばらつきが認められた。一方, Fig. 8 中には溶接金属の中央部のノッチ位置でのシャルピー 試験結果を示しているが，HAZに比べ吸収エネルギーは相 対的に低いものの，ばらつきはいずれの試験温度でも非常 に小さい。

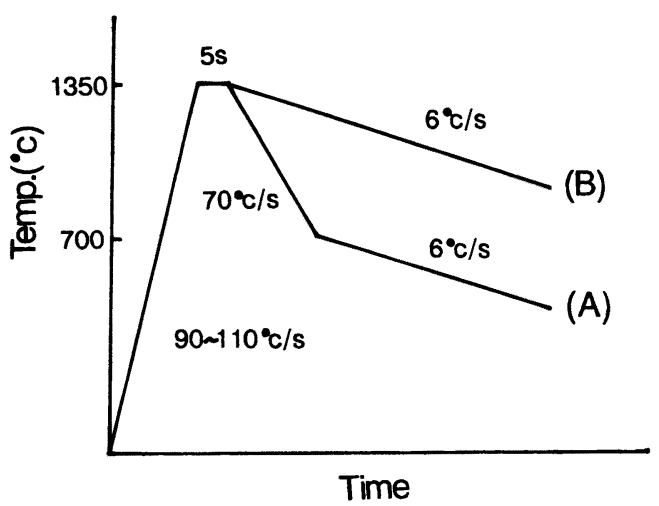

Fig. 7. Schematic illustration of HAZ thermal cycle simulation.

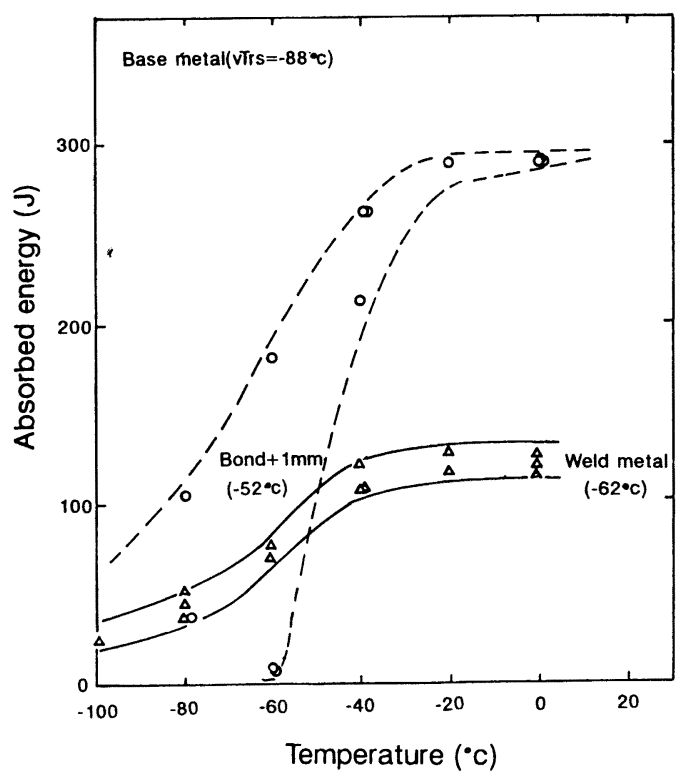

Fig. 8. Results of Charpy impact test of actual HAZ and weld metal.
再現熱サイクル材のシャルピー試験結果をFig. 9 に示寸。 溶接継手の結果と比較すると, 再現熱サイクル材では吸収 エネルギーのばらつく温度範网が小さい。大入熱溶接の冷 却パターンを模擬した笑測パターンによる再現HAZの衝撃 遷移温度は比較パターンによるそれと比べ $16^{\circ} \mathrm{C}$ 高温側に移動 した。なお，本尖験では再現熱サイクル材の上部棚吸収工 ネルギーのばらつきが溶接継手のそれに比べ大きくなって いるが，その原因については不明である。

\section{$3 \cdot 4$ 溶接継手のアイゾット衝撃試験結果}

溶接継手においてはHAZを境に耻材と溶接金属の強度が 異なりこの強度的不均質がHAZの勒性に影響を及ぼすこ とが指摘されている8)。そこで，溶接継手HAZの広い温度範 囲での吸収エネルギーのばらつきについて強度的不均質の 影響の有無を検討するため，アイゾット試験を行った。シ ヤルピー試験と比較すると, アイゾット試験の場合, 試験 片のノッチ底片側から固定されているため, ノッチ底の変 形が打撃側のみに限定される。したがって, 固定側の強度 が極端に大きい場合に相当すると見なせる。

Fig.10は溶接継手のアイゾット試験結果を吸収エネルギー と試験温度との関係で示しているが，その挙動はシャルピ 一試験の場合と比較すると大きく異なっている。すなわち， 吸収エネルギーは高い值と低い值の 2 つのグループに分か

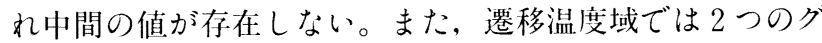
ループが共存し，広い温度範丽で吸収エネルギーがばらつ いている。この結果は, 固定側の組織を溶接金属としても, 母材としても同様であった。これはFig.11(A)に破壊状況を 示しているように，破壞挙動が脆性破壊と延性破壊に極端 に分かれたためである。延性破壊をする場合は，Fig.11(B) に示すように龟裂の伝播方向がノッチの方向からすべり線 場理論によるすべり線の方向に沿って大きくそれ，かつ，

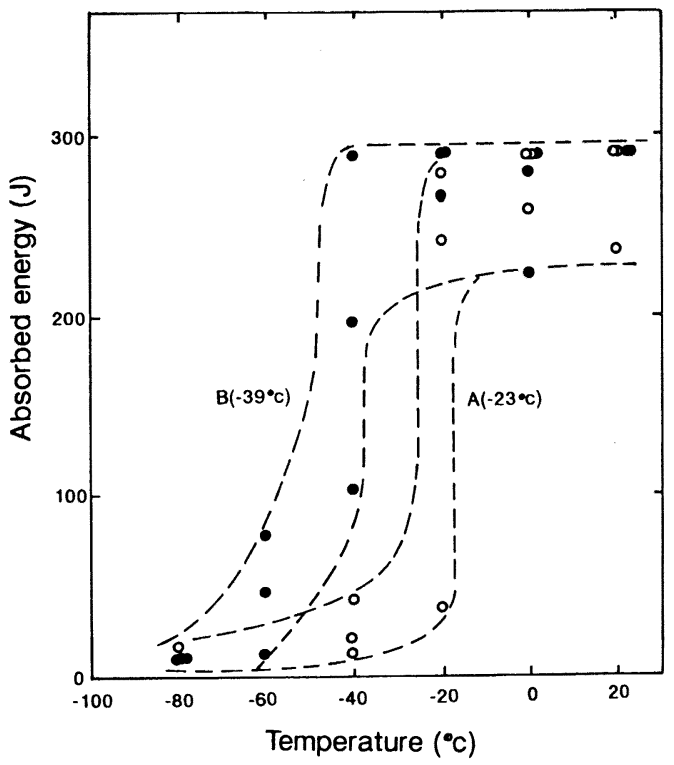

Fig. 9. Results of Charpy impact test of synthetic HAZ.

(xx): vTrs 


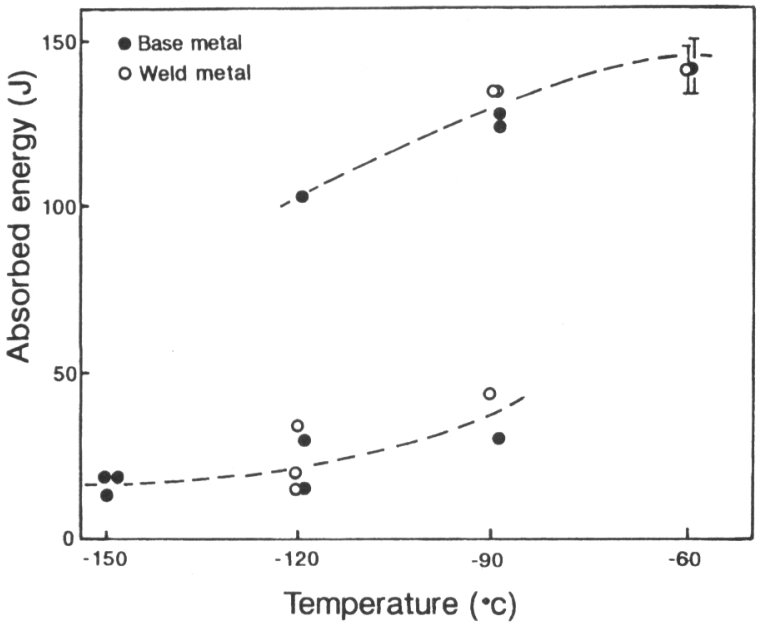

Fig. 10. Results of Izod impact test of actual HAZ and weld metal. Base metal and weld metal in figure mean specimens as shown in Fig. 2 (B) and (C), respectively.
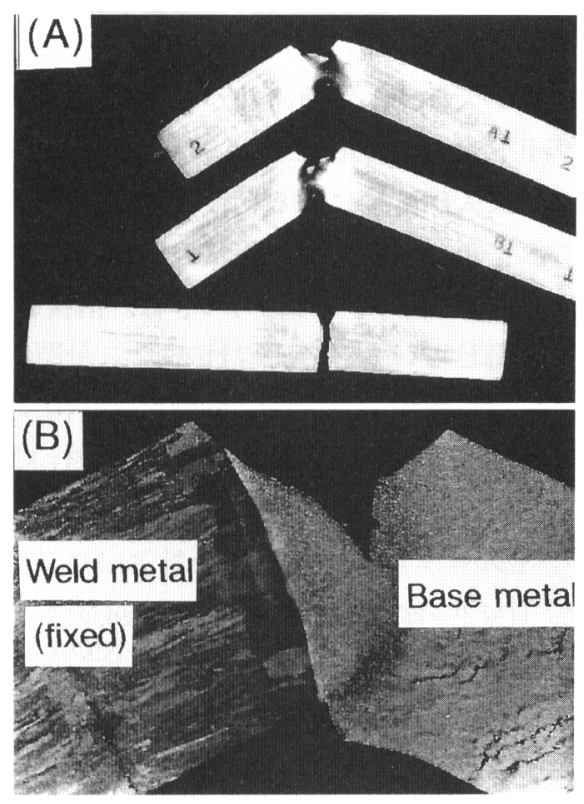

Fig. 11. Izod test pieces after testing.

それる方向はいずれの場合も強度の低い母材側である。

$3 \cdot 5$ 熱サイクルと変態組織の関係

Fig. 9 に示寸再現熱サイクル材の熱サイクルパターンの違 いによる遷移温度の差異は組織的な要因によるものと考え られる。そこで, 熱サイクルにより変態組織がに゙のように 影響を受けるかを検討した。組織観祭に用いた試料はフォ ーマスター試験機によって作製した。熱サイクルは加熱速 度党試験機の最大加熱速度の $200^{\circ} \mathrm{C} / \mathrm{s}$ とし, 実測值に近づけ, 他の条件はFig. 7 と同じ 2 つの伶却パターン (A： 2 段冷却, B：1段冷却) を採用した。

Fig.12にTEM観察結果を示すが，両者いずれも転位を多 〈含む微細なフェライト中に島状マルテンサイト (网中のM) が分散したアシキュラーフェライトを主体とする組織であ
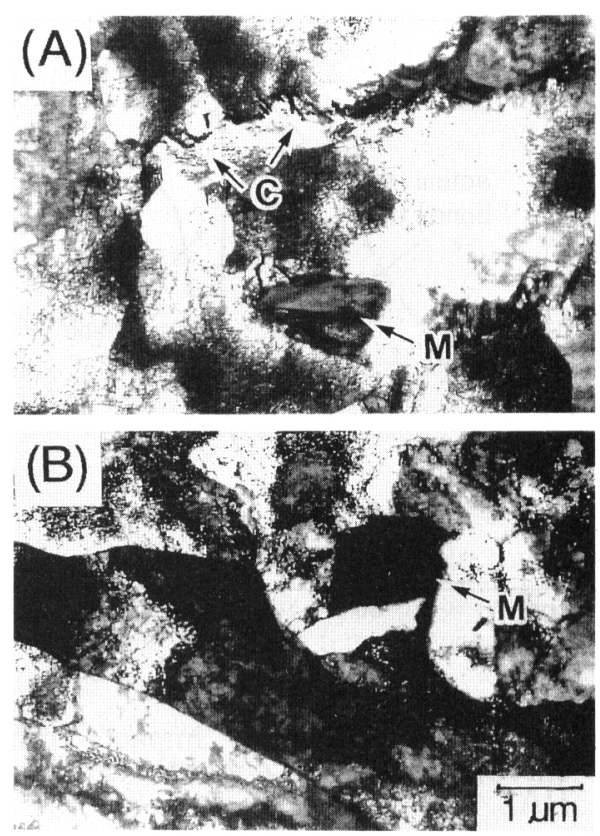

Fig. 12. TEM micrographs of synthetic HAZ. Arrows indicate martensite and cementite segment.

る。しかし, 実測タイプ (A)では疑似パーライト状の組織 (困 中のC)が混在することが恐められた。

\section{4. 考察}

入熱量の増大に伴うHAZの勒性劣化の原因を明らかにす る上で，溶接継手における勒性と組織の関係を明確にする ことは重要であり, 本研究では大入熱溶接の熱サイクルの 特徵を模した 2 段冷却の実測パターンを用いてHAZ組織を 再現した。ここでは大入熱溶接の熱サイクルによる組織変 化々勒性の関係支考察し, 次いで, 組織と䩚性の関係を評 価する妨げとなっている吸収エネルギーのばらつきの要因 について検討する。

\section{$4 \cdot 1$ 大入熱化による勒性劣化と組織の関係}

大入熱化により, 溶接 $\mathrm{HAZ}$ 部の泠却速度は $900 \sim 700^{\circ} \mathrm{C}$ ⿸ 境に大きく変化することが分かった。また，Fig. 9 に示した ように, 大入熱溶接を模擬した実測パターンによる再現HAZ の鞀性は, 従来から使われている比較パターンの鞄性に比 ベ劣化する。これはFig.12に示したように，両パターンでの 変態組織の差異, 寸なわち, 疑似パーライトの有無が影響 していると考えられる。松田ら ${ }^{9)}$ が針状フェライト・パーラ イト組織を有する溶接ボンド部の脆性破壊の起点の詳細観 察から見いだしているように，パーライトは鞓性劣化を引 き起こす重要な組織と考えられる。

パーライトの生成温度は $\mathrm{A}_{1}$ 点以下であり, 本研究で用い た两再現熱サイクルパターンのA 1 点以下の熱履歴は同じで ある。しかし，最高加熱温度から $\mathrm{A}_{1}$ 点付近までの熱履歴が 両パターンで異なっており, 溶接時の变態挙動に $\mathrm{A}_{1}$ 点以上 


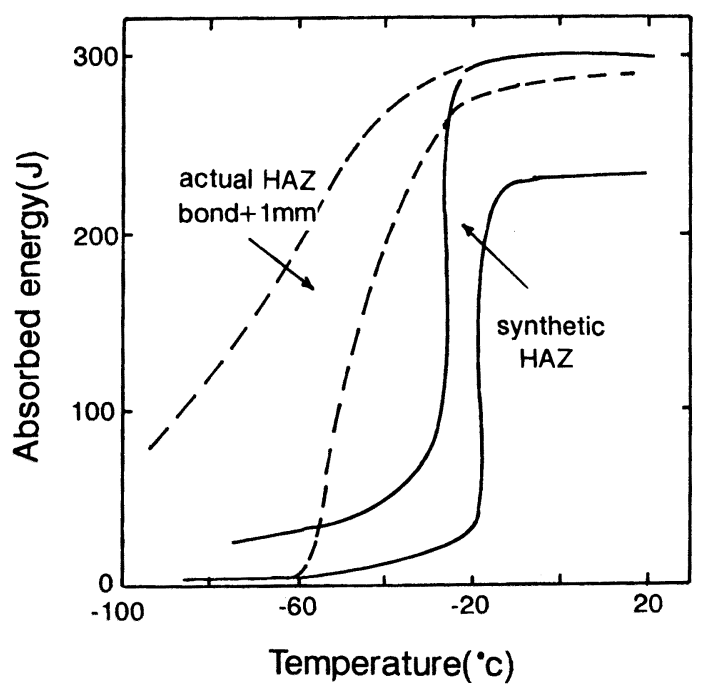

Fig. 13. Relationship between impact transition curve of actual HAZ and that of synthetic HAZ.

の熱履歴か影響を及ぼしていることを示唆している。 $\mathrm{A}_{1}$ 点 以上の熱履歴が疑似パーライトの生成に及ばす影響に関し ては次報10)で述べる。

\section{$4 \cdot 2$ 吸収エネルギーのばらつきの原因}

Fig.13は溶接継手HAZと再現HAZ(実測パターン)の衝撃 試験結果 (Fig.8, 9)をまとめて示したものである。溶接継手 HAZの吸収エネルギーのばらつきは，再現HAZのそれと比 心広い温度範囲にわたっている。また，破面遷移温度は両 者で約 $40^{\circ} \mathrm{C}$ 差があり，再現HAZの遷移温度 $\left(-23^{\circ} \mathrm{C}\right)$ は溶 接継手HAZの吸収エネルギーが低下し始める温度 $(-20$ と $-40^{\circ} \mathrm{C}$ の間)に近い。

溶接継手の吸収エネルギーのばらつきの要因として, 強 度的不均質(亀裂伝播方向の両側の強度の差異) 反映した

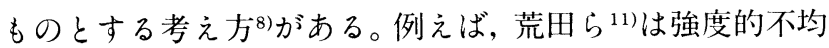
質が非常に大きい電子ビーム溶接材で, 強度的不均質がシ ヤルピー試験の破壊挙動に大きな影響を及ぼし, 遷移温度 域での吸収エネルギーがばらつくことを報告している。同 様の結果は瀬尾と正木 ${ }^{12)}$ にっても報告されている。しかし， アーク溶接継手HAZにおいて, 強度的不均質による吸収工 ネルギーのばらつきへの影響は報告されていない。

本研究の結果はFig.10に示したように，アイゾット試験に より強度的不均質を強調した試験で，前述の荒田らや瀬尾

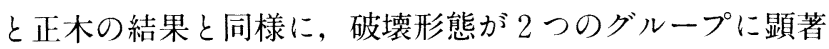

に分かれる結果, 幅広い温度域において吸収エネルギーの ばらつきが観察された。この原因は溶接継手の強度的不均 質により，亀裂の伝播方向が影響を受け，龟裂が軟質側に それる場合とそれない場合の 2 通りに分かれるためである。 すなわち，衝撃試験の低温度域でも龟裂が軟質側にそれた 場合は，吸収エネルギーが高くなるため，吸収エネルギー が大きくばらついたと考えられる。一方，再現HAZの場合 は強度的不均質はないため, 遷移温度域が狭くなると理解 される。したがって，大入熱溶接による勒性劣化は，吸収 エネルギーの低下し始める温度で評洒したほうが破面遷移 温度で評価するより妥当と考えられる。

\section{5. 結言}

大入熱の 2 電極サブマージアーク突き合わせ溶接時の熱 サイクルを実測した結果, 大入熱溶接時のHAZの冷却は 2 段階の泠却パターンで模擬できることがわかった。2段階 のパターンは従来の冷却パターンと比較すると， $\mathrm{A}_{1}$ 点以上 での冷却速度が大きく，等速冷却パターンでは析出しない 疑似パーライトが再現HAZに認められた。この疑似パーラ イトの析出が大入熱溶接による勒性劣化と関係していると 考えられる。また，広範囲な衝撃試験温度域における溶接 継手HAZの吸収エネルギーのばらつきは，溶接継手の強度 的不均質に起因していると考えられる。

最後に熱電対の製作，測定にご協力頂いた神テ製鋼所永 井信幸氏および三晃電気・釣浦寞史氏に感謝致します。

\section{文献}

1 ) 熊倉 靖, 貝原正一郎：溶接学会誌, 58 (1989), 115.

2 ) 笠松 裕, 高嶋修嗣, 細谷隆司：鉄 と銅, 65 (1979), 1232.

3 ) 山本広一, 長谷川俊永, 高村仁一：鉄 と釗, 79 (1993), 1169.

4 ) 笠松 裕, 高嶋修嗣, 細谷隆司：鉄と鎡, 65 (1979), 1222.

5 ) 稻坻道夫, 中村治方, 岡田 明: 溶接学会誌, 34 (1965), 1064.

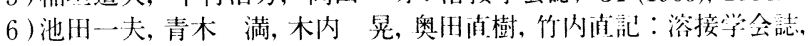
46 (1977), 825.

$7)$ R.M.Denys: Proc. Int. Conf. The Metallurgy, Welding, and Qualification of Microalloyed (HSLA) Steel Weldments. AWS, Minami, (1990), 569.

8 ）豊田政男：溶接学会誌，54 (1985)，71.

9 ）松田昭一，関门昭一，影山英明：鉄と䤱，64（1978）, 1209.

10）金築 裕, 勝亦正昭：鉄と鋼，84（1998），109.

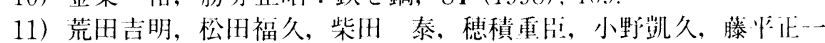
郎：溶接学会誌, 44 (1975), 1011.

12）瀬尾健二, 正木順一：溶接学会誌，51（1982），291. 